\title{
Ambient temperature, birth rate, and birth outcomes: evidence from South Korea
}

\section{Hyunkuk Cho ${ }^{1}$}

Published online: 2 December 2019

(C) Springer Nature B.V. 2019

\begin{abstract}
The effects from rising temperatures, a symptom of climate change, have become a significant concern. This study finds that one additional day with a maximum temperature of $30-32{ }^{\circ} \mathrm{C}\left(86-89.6^{\circ} \mathrm{F}\right)$, relative to a day with a temperature of $28-30{ }^{\circ} \mathrm{C}(82.4-$ $86^{\circ} \mathrm{F}$ ), decreases the birth rate 9 months later by $0.24 \%$, or 92 babies per month in South Korea. This result is robust to various specifications and samples. This study also found that the impact of the temperature bin did not vary according to the mother's characteristics, including education and age. That is, high temperature has no differential effect on mothers of different backgrounds. Finally, we found no significant temperature effect on birth outcomes, but we cannot rule out that children born 9 months after summer heat are a selected (healthy) group.
\end{abstract}

Keywords Summerheat $\cdot$ Birth rate $\cdot$ Birth outcomes $\cdot$ Avoidance behavior $\cdot$ Climate change

\section{Introduction}

The impact of climate change on human life has become a major issue in recent years. The effect of rising temperatures due to greenhouse gas emissions has become even more pronounced. The Intergovernmental Panel on Climate Change (2014) found that, in 2010, global emissions of carbon dioxide were twice that of 1970. Greenhouse gas emissions increase the ambient temperature as they absorb and release radiation in the thermal infrared range. Previous literature has documented the fact that summers have become increasingly hot due to this phenomenon. For example, Habeeb et al. (2015) found that the frequency and intensity of heat waves increased significantly between 1961 and 2010 across 50 US cities.

Hyunkuk Cho

hkcho@ynu.ac.kr

1 School of Economics and Finance, Yeungnam University, 280 Daehak-ro, Gyeongsan 712-749, South Korea 
Few studies have analyzed the relationship between temperature and birth rate. Those that have include Seiver (1985, 1989), Roenneberg and Aschoff (1990), Lam and Miron (1991, 1996), and Barreca et al. (2018). They used relatively old data, ${ }^{1}$ and found a negative relationship between temperature and birth rate; that is, high temperatures reduce the number of births. Barreca et al. (2018), the most recent of the studies, examined data obtained between 1931 and 2010 and found that an additional day with a mean temperature of $80^{\circ} \mathrm{F}$ or higher decreased birth rates 8,9 , and 10 months later, but increased them 11-23 months later; the net effect of these findings is equal to a decrease in birth rate of $0.33 \%$. The study also found that an additional day with a temperature of $80^{\circ} \mathrm{F}$ or higher increased the current month's birth rate and decreased that of the following month. ${ }^{2,3}$ However, they found no significant impact from cold temperatures.

Using data from South Korea, this study examines the effect of temperature on birth rate and birth outcomes. It complements the existing literature as follows. First, this study analyzes relatively recent data, obtained between 2009 and 2013. Presenting results based on recent data can be a valuable addition to the literature because populations adapt to extreme weather; thus, a prediction of the effect of future temperature is likely to be more reliable when it is based on recent data. Second, when estimating the temperature effect, this study compares birth rate and birth outcomes within the same city/month over time. This prevents the possibility of bias when comparing different months in the same city or different cities within the same month. Thus, the analysis is a cohort analysis. According to Hsiang (2016), this is a strengthening of the unit homogeneity assumption because different cohorts within the same unit are comparable. Since the data does not span a long period, the same city/month can be assumed to be homogeneous over time. Third, this study focuses on the influence of summer heat because rising temperatures impact people. Therefore, this study employs daily maximum temperatures rather than the daily average temperatures used in prior studies, because average temperatures may not accurately reflect the extent of the summer heat, as experienced by people.

This study's findings are as follows. One additional day with a maximum temperature of $30-32{ }^{\circ} \mathrm{C}$, relative to a day with a maximum temperature of $28-30{ }^{\circ} \mathrm{C}$, decreases the birth rate 9 months later by $0.24 \%$, or 92 babies per month. This result is robust to various specifications and samples. This study also found that the impact of the temperature bin did not vary according to the mother's characteristics, including education and age. That is, high temperature has no differential effect on mothers of different backgrounds. Finally, we found no significant temperature effect on birth outcomes, but we cannot rule out that children born 9 months after summer heat are a selected (healthy) group.

\footnotetext{
${ }^{1}$ For example, Seiver (1989) used data from 1950 to 1960, while Lam and Miron (1996) used data from 1942 to 1988 .

${ }^{2}$ Temperature has also been found to affect human life spans (Robine et al. 2008; Deschênes and Moretti 2009; Barreca 2012), economic growth (Dell et al. 2012), time use (Graff Zivin and Neidell 2014), crime (Jacob et al. 2007; Ranson 2014), and test scores (Cho 2017; Graff Zivin et al. 2018). See Dell et al. (2014) for the review.

${ }^{3}$ Studies on other weather conditions affecting birth rates include Huber and Fieder (2009) and Cummings (2010), who examined the effects of rain and sunshine, respectively.
} 
The remainder of this paper is organized as follows. The next section reviews the literature, followed by presentation of the data; the "Empirical strategy" section outlines the empirical strategy, which is followed by the estimation results. The "Discussion and conclusion" section concludes the paper.

\section{Literature review}

High temperatures can lead to reduced number of pregnancies due to increased fatigue and heat-related diseases (McMorris et al. 2006; Bai et al. 2014; Nybo et al. 2014), reduced sexual desire (Markey and Markey 2013; Wilde et al. 2017), deterioration of female reproductive health (Sorensen et al. 2018), and decreased sperm count and quality (Levine et al. 1990; Chen et al. 2003; Levitas et al. 2013; Mao et al. 2017). Avoidance or lack of pregnancy because of hot weather decreases the number of newborns 9 months after a heat exposure event. ${ }^{4}$ Resuming efforts to become pregnant immediately thereafter increases the number of newborns 10 months after the heat exposure event (delayed pregnancy). If the pregnancy period is shortened, the number of newborns in the expected month will decrease. For example, if the pregnancy period is shortened by 1 month, babies that were expected to be born 1 month later will be born in this month. In this case, this month will see an increase in the number of newborns, and the next month will see a decrease. ${ }^{5}$

Studies on the effect of temperature on birth outcomes have shown mixed results. Some studies found that high temperatures cause a low birth weight (Deschênes et al. 2009; Andalón et al. 2016; Barreca et al. 2018) and preterm births (Dadvand et al. 2011; Strand et al. 2011; Barreca et al. 2018), possibly because, at high temperatures, blood flow to the uterus decreases (Basu et al. 2010) and the body secretes stress hormones, such as cortisol (Yackerson et al. 2008). However, other studies found no significant effect on birth outcomes (Porter et al. 1999; Tustin et al. 2004; Lee et al. 2008). ${ }^{6}$

\section{Data}

This study analyzes birth and population data from the National Statistical Office for the period of 2009 to 2013 and weather data from Korean Meteorological Administration for the period of 2008 to 2013. The birth data are based on registrations of newborns in all 162 cities in the country, which include information on the birth year/month, gender, birth weight, gestational length, and parental ages and education levels. ${ }^{7}$ The total number of newborns for the 5-year period is 2.3 million, and for each year, it is 444,849 (2009), 470,171 (2010), 471,265 (2011), 484,550 (2012), and

\footnotetext{
4 The term "9 months" in this paper refers to $36-40$ weeks into a pregnancy.

${ }^{5}$ Lam et al. (1994) presented a fertility model incorporating coital frequency and fetal loss.

${ }^{6}$ Studies examining the effects of temperature in utero on other outcomes include Isen et al. (2015) and Wilde et al. (2017), respectively. Studies analyzing other shocks to the in utero environment include Almond et al. (2009), Black et al. (2013), Sanders (2012), and Hoynes et al. (2016). For earlier studies on the relationship between the in utero environment and birth or later outcomes, see Almond and Currie (2011).

${ }^{7}$ The government requires parents to register their newborns within a month of birth.
} 
436,455 (2013) with an average of 461,458 . The yearly average for the 162 cities is 2848 and the median is 669 .

The population data include information on the number of residents in each city/year. The data are based on local registrations, and the number of residents is the average resident numbers on the first and last days of each year. The weather data include information on daily maximum temperature and precipitation at the city level. All are taken from actual weather stations, but in the case of the seven cities around Seoul without stations, Seoul's weather data are used instead., ${ }^{8,9}$

Table 1 shows the number of days per month with a daily maximum temperature in the given range for cities. For example, for $\geq 32{ }^{\circ} \mathrm{C}$, a city in the bottom 25 th percentile has 1.2 days per month, or 14.4 days $(=1.2 \times 12)$ per year, and a city in the top 25 th percentile has 2.2 days per month, or 26.4 days $(=2.2 \times 12)$ per year. The table also shows the number for each month. For example, August, the hottest month, has an average of 10.9 days of temperatures $\geq 32{ }^{\circ} \mathrm{C}$, followed by July, with 5.2 days.

Table 2 presents data (at the city/year-month level) on newborns and their mothers. The daily birth rate is 2.24 , which means over the 5 years, an average of 2.24 children per 100,000 residents was born each day. The rate is defined as the number of newborns in a month divided by the number of days in the month, divided by the city/year population, and then multiplied by 100,000 . In addition, the proportions of girls and babies of low birth weight are $48.5 \%$ and $5.2 \%$, respectively.

\section{Empirical strategy}

Consider birth rate regression Eq. (1) for city $c$ and year/month $t$. The subscripts $m$ and $y$ represent the calendar month and year, respectively.

$$
\begin{aligned}
\ln \left(\mathrm{A}_{\mathrm{ct}}\right)= & \beta_{0}+\sum_{j=1}^{6} \sum_{k=0}^{12} \beta_{k}^{j} \operatorname{Temp}_{c t-k}^{j}+\sum_{i=1}^{3} \sum_{k=0}^{12} \lambda_{k}^{i} \operatorname{Rain}_{c t-k}^{i}+\mathbf{X}_{\mathbf{c t}} \mathbf{B}_{\mathbf{1}}+\eta_{c m}+\gamma_{t}+\delta_{c y} \\
& +\nu_{c} \times t+\nu_{c} \times t^{2}+\varepsilon_{c t}
\end{aligned}
$$

The dependent variable is the natural log of birth rate, which is defined in the "Data" section. Temp is a variable representing the daily maximum temperature of each month and consists of the following six categories: $<22{ }^{\circ} \mathrm{C}, 22-24{ }^{\circ} \mathrm{C}, 24-26{ }^{\circ} \mathrm{C}, 26-28{ }^{\circ} \mathrm{C}$, $30-32{ }^{\circ} \mathrm{C}$, and $\geq 32{ }^{\circ} \mathrm{C}$. Using categorical variables for temperature is now standard across the literature (Dell et al. 2014). For example, $\geq 32{ }^{\circ} \mathrm{C}$ indicates the number of days in a month for which the daily maximum temperature is equal to or greater than $32{ }^{\circ} \mathrm{C}$. The superscript 6 of the Temp variable represents $\geq 32{ }^{\circ} \mathrm{C}$, and 1 represents < $22{ }^{\circ} \mathrm{C}$. The bin of $28-30{ }^{\circ} \mathrm{C}$ is excluded from the equation and is used as a comparison category. ${ }^{10}$ If no bin is excluded, the coefficients for each temperature bin indicate the value of the dependent variable, and, therefore, one should compare the coefficients to

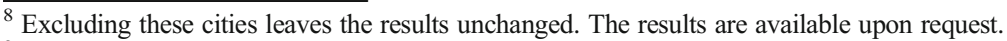

${ }^{9}$ The birth, population, and weather data can be downloaded or obtained on request at https://mdis.kostat.go. $\mathrm{kr} / \mathrm{index} . \mathrm{do}$, http://kosis.kr/eng/, and https://data.kma.go.kr/cmmn/main.do, respectively.

${ }^{10}$ While there is no established theory that allows us to choose a comparison category, we chose it because Koreans generally feel hot when the temperature reaches $30^{\circ} \mathrm{C}$ or higher.
} 
Table 1 The average number of days per month with a daily maximum temperature in the given range: distribution for city and month

\begin{tabular}{|c|c|c|c|c|c|c|c|c|c|c|c|c|c|c|c|}
\hline & \multicolumn{3}{|l|}{ City } & \multicolumn{12}{|c|}{ Month } \\
\hline & $25 \%$ & $50 \%$ & $75 \%$ & Jan & Feb & Mar & Apr & May & June & July & Aug & Sept & Oct & Nov & Dec \\
\hline$\geq 32{ }^{\circ} \mathrm{C}$ & 1.2 & 1.6 & 2.2 & 0 & 0 & 0 & 0 & 0.2 & 2.4 & 5.2 & 10.9 & 1.0 & 0 & 0 & 0 \\
\hline $30-32{ }^{\circ} \mathrm{C}$ & 2.0 & 2.3 & 2.5 & 0 & 0 & 0 & 0 & 1.1 & 5.6 & 7.7 & 7.7 & 3.4 & 0 & 0 & 0 \\
\hline $28-30{ }^{\circ} \mathrm{C}$ & 2.5 & 2.7 & 2.8 & 0 & 0 & 0 & 0.3 & 3.4 & 7.0 & 7.3 & 6.2 & 5.7 & 0.2 & 0 & 0 \\
\hline $26-28{ }^{\circ} \mathrm{C}$ & 2.2 & 2.5 & 2.7 & 0 & 0 & 0.1 & 0.6 & 4.9 & 6.6 & 6.0 & 4.0 & 7.0 & 1.3 & 0 & 0 \\
\hline $24-26{ }^{\circ} \mathrm{C}$ & 2.0 & 2.2 & 2.5 & 0 & 0 & 0.1 & 1.1 & 5.9 & 4.3 & 3.8 & 1.6 & 6.4 & 4.1 & 0.4 & 0 \\
\hline $22-24^{\circ} \mathrm{C}$ & 1.8 & 1.9 & 2.2 & 0 & 0.1 & 0.4 & 2.1 & 5.6 & 2.7 & 0.8 & 0.5 & 3.7 & 7.5 & 0.8 & 0 \\
\hline$<22{ }^{\circ} \mathrm{C}$ & 16.4 & 17.2 & 17.8 & 31 & 28.2 & 30.5 & 25.8 & 9.9 & 1.4 & 0.2 & 0.1 & 2.8 & 17.8 & 28.7 & 31 \\
\hline
\end{tabular}

The number for each city is calculated by dividing the number of days for each bin in a city in a year by 60 (= 12 months $\times 5$ years). The number for the month is calculated by dividing the weighted sum of days for each bin in a city in a month by 810 (=162 cities $\times 5$ years $)$. City/year populations are used as the weight

Source: The author's own calculation based on the weather and population data

examine how a temperature bin affects the birth rate relative to another temperature bin. Excluding a bin exempts us from doing so. This study includes the temperature of the current month and past temperatures from up to 12 months prior in the equation. If, for example, Temp ${ }_{c t-9}$ has a value of 3 , then city $c$ experienced 3 days of maximum temperature of $\geq 32{ }^{\circ} \mathrm{C} 9$ months previously. In addition, Rain is a variable representing the total precipitation of each month and consists of the following three categories: <

Table 2 Summary statistics on newborns and their mothers

\begin{tabular}{lll}
\hline & Mean & Standard deviation \\
\hline Birth rate & 2.24 & 0.70 \\
Girl (\%) & 48.5 & 8.3 \\
Birth weight (g) & 3212 & 83.2 \\
Low birth weight (\%) & 5.2 & 4.1 \\
Gestational length (week) & 38.7 & 0.33 \\
Preterm birth (\%) & 6.2 & 4.6 \\
Mother-no college degree (\%) & 39.1 & 11.9 \\
Mother's age & 30.9 & 1.0 \\
Mother-35 years or older (\%) & 16.6 & 6.9 \\
Teen mother $(\%)$ & 1.0 & 1.9 \\
Number of cities & 162 & \\
Number of city/year-month & 9718 & \\
\hline
\end{tabular}

Birth rate is defined as the number of newborns in a month divided by the number of days in the month, divided by the city/year population, multiplied by 100,000 . Thus, the birth rate is the average daily number of newborns per 100,000 residents. Low birth weight means weighing less than $2500 \mathrm{~g}$ at birth, and preterm birth means being born before 37 weeks OF pregnancy

Source: The author's own calculation based on the birth registry and population data 
$34 \mathrm{~mm}, 72-150 \mathrm{~mm}$, and $\geq 150 \mathrm{~mm} .^{11}$ The bin of $34-72 \mathrm{~mm}$ is excluded from the equation, and the equation includes the rainfall of the current month and the past 12 months. This variable is included because it is known to affect health outcomes (Dell et al. 2014). The vector $\mathbf{X}$ includes the mothers' average age and education at the city/year-month level. Education is the proportion of mothers with no college degree. These variables are included because the mother's characteristics are likely to affect the number of births.

Although the maximum temperature in a city on a given day is determined randomly, following Barreca et al. (2018), this study includes a variety of fixed effects in the regression to address the confounding of unobserved factors. In the equation, $\eta$ is the city/month fixed effect, and thus the birth rate of the same city/month is compared over time. That is to say, the January birth rate of a city in a year is compared with the January birth rate of the city in other years. Without this variable, it is difficult to know whether the differences in birth rates are due to variations in temperature or variations in characteristics of the month or of cities. $\gamma$ is the year/month fixed effect. This variable controls for factors affecting the whole country in a certain year/month. For example, avoiding pregnancy when suspecting, say, a Middle East respiratory syndrome coronavirus infection will reduce the number of newborns 9 months later. If we do not control for this variable, we cannot tell whether the low number of newborns can be attributed to the virus or to the weather.

In addition, $\delta$ is the city/year fixed effect. This variable controls for factors affecting a certain city/year. For example, if a city experiences an economic recession in 2012, leading residents to postpone marriage and childbirth, the number of newborns will decline in 2013. The city/year fixed effects can control for such factors. Finally, $v_{\mathrm{c}} \times t$ and $v_{\mathrm{c}} \times t^{2}$ are the interactions between city fixed effects and time trend variables $t$ and $t^{2}$, respectively.

Equation (1) is estimated using ordinary least squares. The regression includes 9718 (= 162 cities $\times 5$ years $\times 12$ months -2 ) observations. Two city/year-months are excluded from the analysis because the number of newborns is zero in those cases and it is not possible to take the log. The coefficients of interest are the coefficients for the Temp variable. Although Eq. (1) includes a variety of fixed effects to control for unobserved factors, the estimates could be biased if there are factors affecting both temperature and the birth rate. One possible factor is air pollution, which may cause global warming and affect the birth rate. However, a temperature rise due to air pollution occurs gradually, not abruptly. That is, air pollution occurring in a certain month is not likely to affect temperature in the near future and thus is not likely to bias the estimates. Even if this were the case, one of the fixed effects can control for air pollution, as long as it affects the entire country (or city) in a certain year (or month).

It is noteworthy that the estimates include the impact of avoidance behaviors (e.g., staying indoors or using air conditioning) because people engage in such behaviors in response to high temperatures. Hence, the interpretation of the result should reflect this behavior. That is, the estimates reflect both the effect of the temperature and the effect of such behaviors.

Finally, this study also analyzes the impact of temperature on birth outcomes, including the probability of a low birth weight and of preterm birth. For the former, the dependent variable is the proportion of babies with low birth weight, and the independent variables are the same as those in regression Eq. (1). When estimating the impact on birth outcomes, the number of newborns in each city/month is used as the weight.

\footnotetext{
${ }^{11}$ These numbers were chosen because each category has an equal share. When this study used other categories, including $<50 \mathrm{~mm}, 100-300 \mathrm{~mm}$, and $\geq 300 \mathrm{~mm}$, the results did not change.
} 


\section{Results}

\section{The effect of temperature on birth rate}

Table 3 shows the result of the regression using Eq. (1). Each column of the table presents the temperature effect 0-12 months after summer heat. In addition, multiplying the dependent variable by 100 , a coefficient of, say, -0.3 , can be interpreted as a $0.3 \%$ reduction in the birth rate. According to the table, an additional day with a maximum temperature of $30-32{ }^{\circ} \mathrm{C}$, relative to a day with a maximum temperature of $28-30{ }^{\circ} \mathrm{C}$, decreases the birth rate 9 months later by $0.24 \%$. This result is consistent with the findings of Barreca et al. (2018), who showed that in the $2000 \mathrm{~s}$, an additional day with a mean temperature of $80^{\circ} \mathrm{F}$ or higher reduced the birth rate 9 months later by $0.2 \%$.

The effect size of $0.24 \%$ found in this study is equivalent to 92 fewer babies per month in the entire country because an annual average of 461,458 , or a monthly average of 38,455 (= $461,458 / 12$ ), was born in the country during the 5 years, and $0.24 \%$ of the monthly average is 92 . The reduced birth rate 9 months after an incidence of high temperature means there were reduced pregnancies due to the hot weather. In addition, the lack of evidence of a change in the birth rate in other months, as shown in Table 3, means there was no shift in birth months. That is, we found no evidence of any shortening of pregnancy length or delayed pregnancy. ${ }^{12}$ In Table 3 , although no coefficients for the maximum temperature of $\geq 32{ }^{\circ} \mathrm{C}$ are statistically significant, some of them are fairly large in absolute value, implying that we cannot rule out large impacts in some months. ${ }^{13}$

Finally, we also estimated the average temperature effect, as in the previous studies. The temperature bins are $\geq 25^{\circ} \mathrm{C}, 20-25{ }^{\circ} \mathrm{C}, 10-15^{\circ} \mathrm{C}, 5-10{ }^{\circ} \mathrm{C}, 0-5{ }^{\circ} \mathrm{C},<0{ }^{\circ} \mathrm{C}$, and the bin of $15-20^{\circ} \mathrm{C}$ is omitted to be used as a comparison category. As Table 4 shows no estimates are statistically significant.

\section{Robustness checks}

As a robustness check, we control for humidity in the regression equation. The analysis is limited to 81 cities because not every city has humidity data. When we limit the analysis to 81 cities without controlling for humidity, the birth rate 9 months after the daily maximum temperature of $30-32{ }^{\circ} \mathrm{C}$ reduces by $0.237 \%$. When we control for it, the result remains unchanged at $0.245 \%$. Other coefficients also do not show a difference. This implies that humidity does not affect the temperature-fertility relationship.

We also estimated the temperature effect by adding bins of lower temperatures. The following temperature bins were added to the original ones in Eq. (1): $19-22{ }^{\circ} \mathrm{C}, 16-$ $19{ }^{\circ} \mathrm{C}, \ldots, 1-4{ }^{\circ} \mathrm{C}$, and $<1{ }^{\circ} \mathrm{C}$. Again, the bin of $28-30{ }^{\circ} \mathrm{C}$ was excluded. Table 5 shows that the result is not different from that in Table 3 . That is, an additional day with

\footnotetext{
${ }^{12}$ As shown in Table 3, the coefficient for the effect 10 months after the maximum temperature of $30-32{ }^{\circ} \mathrm{C}$ is 0.131 . If some pregnancies, if any at all, did not take 10 months, the estimate would be larger, which implies that we might have evidence of (significant) delayed pregnancy.

${ }^{13}$ This study also estimates the effects of temperatures of $32-34{ }^{\circ} \mathrm{C}$ and $\geq 34{ }^{\circ} \mathrm{C}$. However, no significant effects are found in either category. This implies that people engage in heat-avoidance behavior if the weather is too hot.
} 


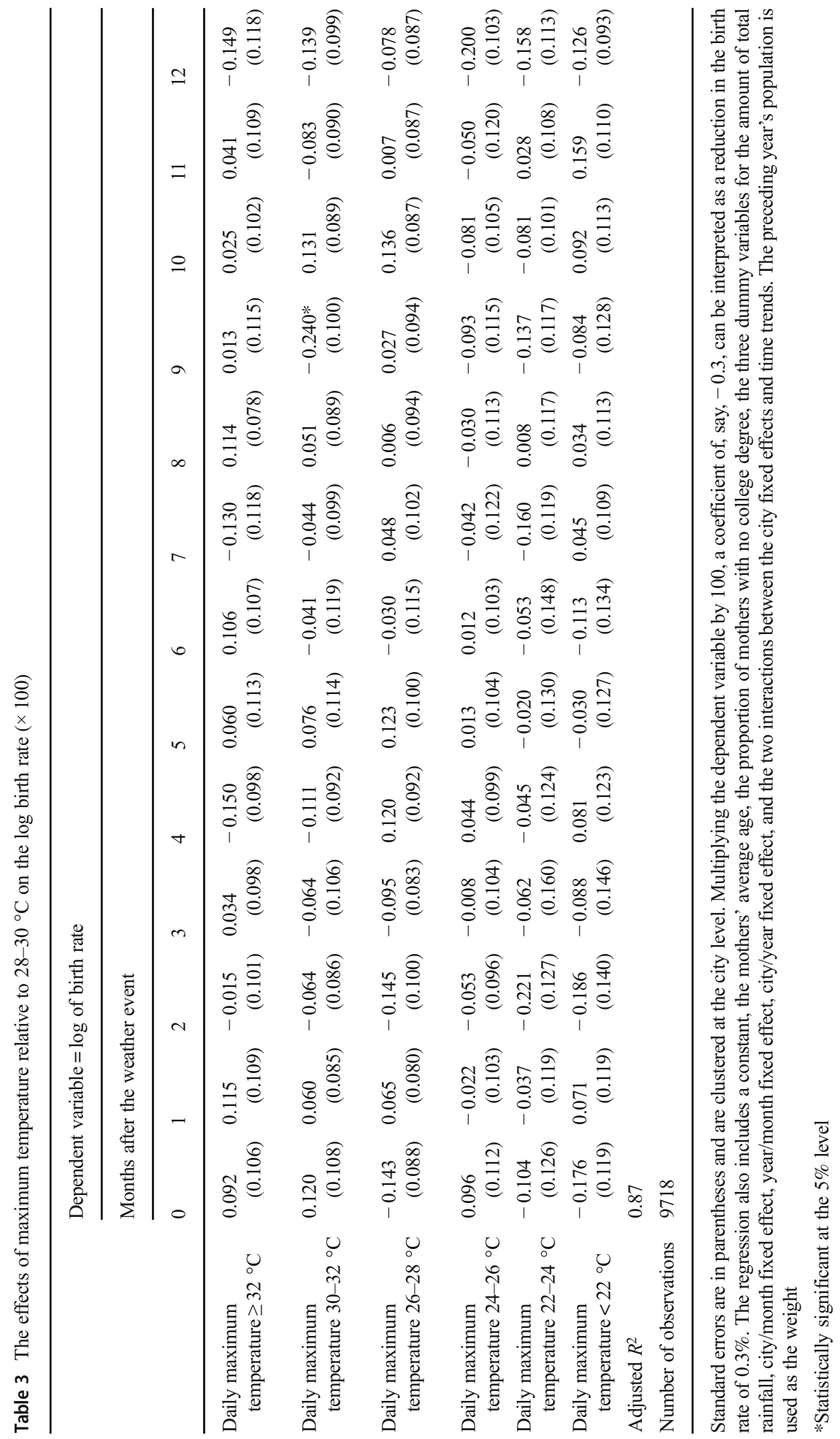




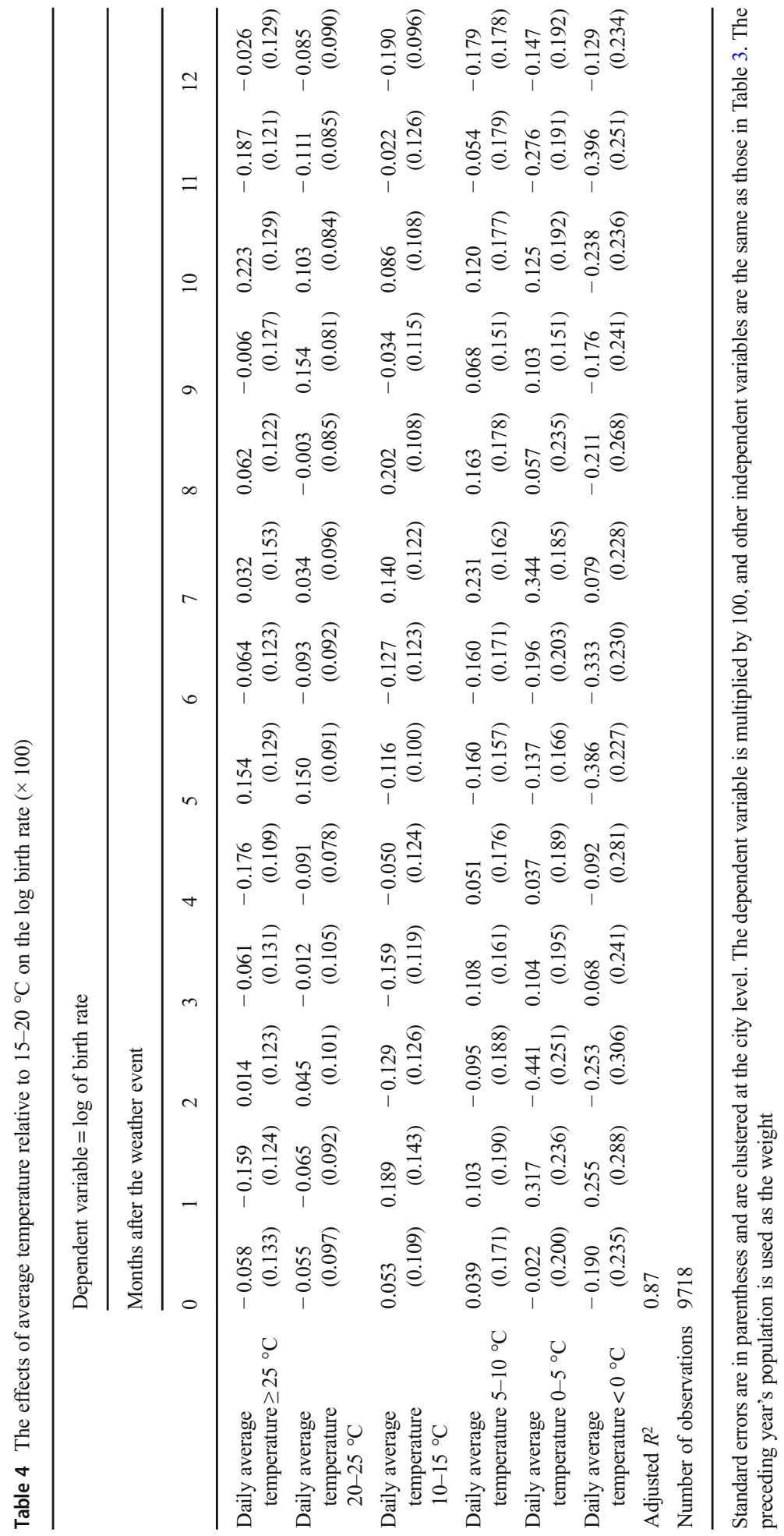


Table 5 The effects of maximum temperature relative to $28-30{ }^{\circ} \mathrm{C}$ on the log birth rate $(\times 100) 9$ months after the weather event using the full distribution of temperatures

Dependent variable $=\log$ of birth rate

\begin{tabular}{ll}
\hline Daily maximum temperature $\geq 32{ }^{\circ} \mathrm{C}$ & $-0.029(0.116)$ \\
Daily maximum temperature $30-32{ }^{\circ} \mathrm{C}$ & $-0.231 *(0.102)$ \\
Daily maximum temperature $26-28{ }^{\circ} \mathrm{C}$ & $0.067(0.111)$ \\
Daily maximum temperature $24-26{ }^{\circ} \mathrm{C}$ & $-0.125(0.131)$ \\
Daily maximum temperature $22-24^{\circ} \mathrm{C}$ & $-0.163(0.127)$ \\
Daily maximum temperature $19-22{ }^{\circ} \mathrm{C}$ & $-0.110(0.156)$ \\
Daily maximum temperature $16-19{ }^{\circ} \mathrm{C}$ & $-0.180(0.171)$ \\
Daily maximum temperature $13-16^{\circ} \mathrm{C}$ & $-0.253(0.169)$ \\
Daily maximum temperature $10-13{ }^{\circ} \mathrm{C}$ & $-0.184(0.183)$ \\
Daily maximum temperature $7-10^{\circ} \mathrm{C}$ & $-0.073(0.156)$ \\
Daily maximum temperature $4-7{ }^{\circ} \mathrm{C}$ & $-0.256(0.200)$ \\
Daily maximum temperature $1-3{ }^{\circ} \mathrm{C}$ & $-0.251(0.203)$ \\
Daily maximum temperature $<1{ }^{\circ} \mathrm{C}$ & $0.026(0.238)$ \\
Adjusted $R^{2}$ & 0.87 \\
Number of observations & 9718 \\
\hline
\end{tabular}

Standard errors are in parentheses and are clustered at the city level. The dependent variable is multiplied by 100 , and other independent variables are the same as those in Table 3. The preceding year's population is used as the weight

a maximum temperature of $30-32{ }^{\circ} \mathrm{C}$, relative to a day with a maximum temperature of $28-30{ }^{\circ} \mathrm{C}$, decreases the birth rate 9 months later by $0.23 \%$.

For the third robustness check, we estimated the temperature effect using past temperatures from up to 20 months prior and found that this also did not change the result. As shown in Table 6, the coefficient for $30-32{ }^{\circ} \mathrm{C}$ is -0.291 . For the last robustness test, to determine whether a particular city drives the result in Table 3, we excluded one city at a time. The choice of cities was made from the largest seven cities in the country, which have higher birth rates than the average birth rate. They are Seoul, the capital city, along with Daejeon, Gwangju, Incheon, and Ulsan. ${ }^{14}$ As shown in Table 7, the exclusion leaves the coefficients unchanged. For example, when Seoul is excluded, the coefficient for $30-32{ }^{\circ} \mathrm{C}$ is -0.237 .

\section{Who is affected and how are they affected by high temperature?}

Table 3 shows that high temperature reduces the number of births 9 months later. To investigate who is affected by the high temperature, this section estimates the temperature's effect on the mothers' characteristics, including education and age. Less educated and older or teen mothers could be affected more by a high temperature, possibly because they may have less knowledge about heat avoidance and may be less healthy. That is, the reduced births shown in Table 3 could be due to these types of mothers. The dependent variables of the analyses in Table 8 are the percentages of mothers with no

\footnotetext{
${ }^{14}$ Figure 1 shows the map of the country. The country is divided into the seven largest cities and nine provinces, including Gyunggi surrounding Seoul. The other two large cities are Busan and Daegu.
} 


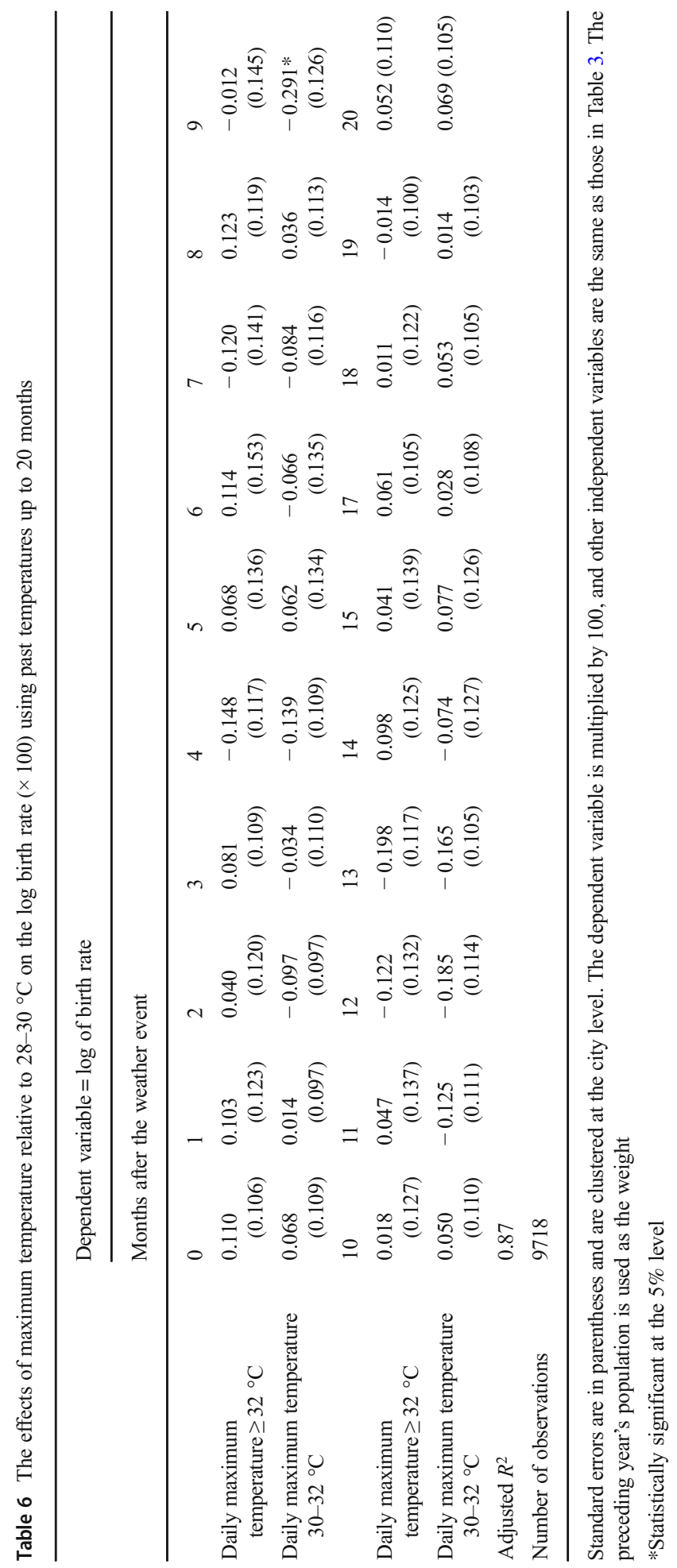


Table 7 The effects of maximum temperature relative to $28-30{ }^{\circ} \mathrm{C} 9$ months after the weather event on the log birth rate $(\times 100)$ excluding a city at a time

\begin{tabular}{|c|c|c|c|c|c|}
\hline & \multicolumn{5}{|c|}{ Dependent variable $=\log$ of birth rate } \\
\hline & $\begin{array}{l}\text { Seoul } \\
\text { excluded (1) }\end{array}$ & $\begin{array}{l}\text { Daejeon } \\
\text { excluded (2) }\end{array}$ & $\begin{array}{l}\text { Gwangju } \\
\text { excluded (3) }\end{array}$ & $\begin{array}{l}\text { Incheon } \\
\text { excluded (4) }\end{array}$ & $\begin{array}{l}\text { Ulsan } \\
\text { excluded (5) }\end{array}$ \\
\hline $\begin{array}{l}\text { Daily maximum } \\
\quad \text { temperature } \geq 32{ }^{\circ} \mathrm{C}\end{array}$ & $\begin{array}{r}-0.011 \\
\quad(0.116)\end{array}$ & $0.020(0.123)$ & $0.035(0.114)$ & $\begin{array}{r}-0.023 \\
(0.113)\end{array}$ & $0.022(0.115)$ \\
\hline $\begin{array}{l}\text { Daily maximum temperature } \\
\quad 30-32{ }^{\circ} \mathrm{C}\end{array}$ & $\begin{array}{r}-0.237 * \\
(0.105)\end{array}$ & $\begin{array}{r}-0.255^{*} \\
(0.108)\end{array}$ & $\begin{array}{r}-0.233^{*} \\
(0.103)\end{array}$ & $\begin{array}{r}-0.254 * \\
(0.107)\end{array}$ & $\begin{array}{r}-0.246^{*} \\
(0.103)\end{array}$ \\
\hline Adjusted $R^{2}$ & 0.86 & 0.87 & 0.86 & 0.87 & 0.86 \\
\hline Number of observations & 9658 & 9658 & 9658 & 9658 & 9658 \\
\hline
\end{tabular}

Standard errors are in parentheses and are clustered at the city level. The dependent variable is multiplied by 100 , and other independent variables are the same as those in Table 3. The preceding year's population is used as the weight

college degree, of mothers aged 35 or older, and of teen mothers. In addition, the estimates in the table are the effect 9 months after the weather event. The table shows that a high temperature does not affect the mothers' characteristics. While the coefficients for $30-32{ }^{\circ} \mathrm{C}$ in columns (1) and (3) are negative, they are not significant, and the positive coefficient in column (2) is not significant either.

When the weather is hot, the number of births may reduce for the following reasons. As described in the "Literature review" section, people may reduce coital frequency, possibly due to heat-related fatigue (a behavioral factor). Even if the frequency is not reduced, the probability of conception may decline as a result of decreased sperm count and/or quality and deteriorated female reproductive health (a biological factor). Although this study cannot examine how each factor explains the temperature effect due to a lack of data, the reduced number of pregnancies 9 months after summer heat, as found in Table 3, can be reasonably attributed to these two factors.

\section{Temperature effect on birth outcomes}

This study estimates the temperature effect on birth outcomes. As the "Literature review" section describes, high temperatures may cause low birth weight and preterm births, although some studies did not find evidence of this. Table 9 shows the results, with each panel representing one regression. As shown in the two panels of the table, no estimates in the table are statistically significant.

Although no estimates in Table 9 are statistically significant, it cannot be concluded that summer heat does not cause unhealthy babies because, considering that babies not conceived because of summer heat would have been born with worse birth outcomes if they had been conceived and born, the estimates of this study could underestimate the true effect of temperature on birth outcomes. That is, the estimates in Table 9 are possibly biased by selection. 
Table 8 The effects of maximum temperature relative to $28-30{ }^{\circ} \mathrm{C}$ on mothers' characteristics 9 months after the weather event

\begin{tabular}{|c|c|c|c|}
\hline & \multicolumn{3}{|c|}{ Dependent variable $=$ proportion of } \\
\hline & $\begin{array}{l}\text { Mother-no } \\
\text { college degree }(\%)(1)\end{array}$ & $\begin{array}{l}\text { Mother-35 years } \\
\text { or older }(\%)(2)\end{array}$ & $\begin{array}{l}\text { Teen } \\
\text { mother }(\%)(3)\end{array}$ \\
\hline Daily maximum temperature $\geq 32{ }^{\circ} \mathrm{C}$ & $-0.027(0.045)$ & $-0.007(0.042)$ & $0.001(0.008)$ \\
\hline Daily maximum temperature $30-32^{\circ} \mathrm{C}$ & $-0.069(0.047)$ & $0.006(0.035)$ & $-0.003(0.009)$ \\
\hline Daily maximum temperature $26-28^{\circ} \mathrm{C}$ & $-0.068(0.037)$ & $0.004(0.036)$ & $0.007(0.009)$ \\
\hline Daily maximum temperature $24-26^{\circ} \mathrm{C}$ & $-0.034(0.047)$ & $-0.010(0.042)$ & $0.005(0.009)$ \\
\hline Daily maximum temperature $22-24^{\circ} \mathrm{C}$ & $-0.105^{*}(0.047)$ & $0.001(0.044)$ & $-0.003(0.010)$ \\
\hline Daily maximum temperature $<22{ }^{\circ} \mathrm{C}$ & $-0.095^{*}(0.047)$ & $-0.038(0.045)$ & $0.012(0.011)$ \\
\hline Adjusted $R^{2}$ & 0.88 & 0.62 & 0.13 \\
\hline Number of observations & 9718 & 9718 & 9718 \\
\hline
\end{tabular}

Standard errors are in parentheses and are clustered at the city level. Other independent variables are the same as those in Table 3. The number of newborns is used as the weight

\section{Discussion and conclusion}

This study estimated the effect of temperature on birth rates and birth outcomes for newborns in Korea between 2009 and 2013. The results showed that an additional day with a maximum temperature of $30-32{ }^{\circ} \mathrm{C}$, relative to a day with a maximum temperature of $28-30{ }^{\circ} \mathrm{C}$, decreased the birth rate 9 months later by $0.24 \%$, or 92 babies per month. This study also found high temperatures have no differential effect on mothers of different backgrounds.

The effects on the birth rate found in this study are smaller than the effects found in Barreca et al. (2018). The difference may arise because the present study examines relatively recent data, while Barreca et al. (2018) analyze data obtained from 1931 to 2010 . That is to say, people in modern times may respond differently to summer heat than people in the past. The former may use air conditioning more frequently than the latter and might be more accustomed to summer heat because they experience hot days more frequently. In fact, Barreca et al. (2018) found that the effect size declined after the 1960s. One additional factor that may make a difference in the two studies is that the mothers included in this study have a relatively high level of education. As shown in Table 2, mothers with no college degree account only for $39 \%$, and the rest have a higher degree. Assuming that highly educated people have more knowledge about heat avoidance and more resources to follow through on this knowledge, this study should find smaller temperature effects.

Korea has a fertility rate lower than any other industrialized country, which could lead to severe labor shortages in the near future. ${ }^{15}$ Though high temperatures have been found to have the potential to reduce the rate further, people can

\footnotetext{
${ }^{15}$ The total fertility rate is 1.05 in 2017 . This data can be downloaded at the following website of National Statistical Office.

http://kosis.kr/statHtml/statHtml.do?orgId=101\&tblId=DT_1B8000F\&language=en
} 


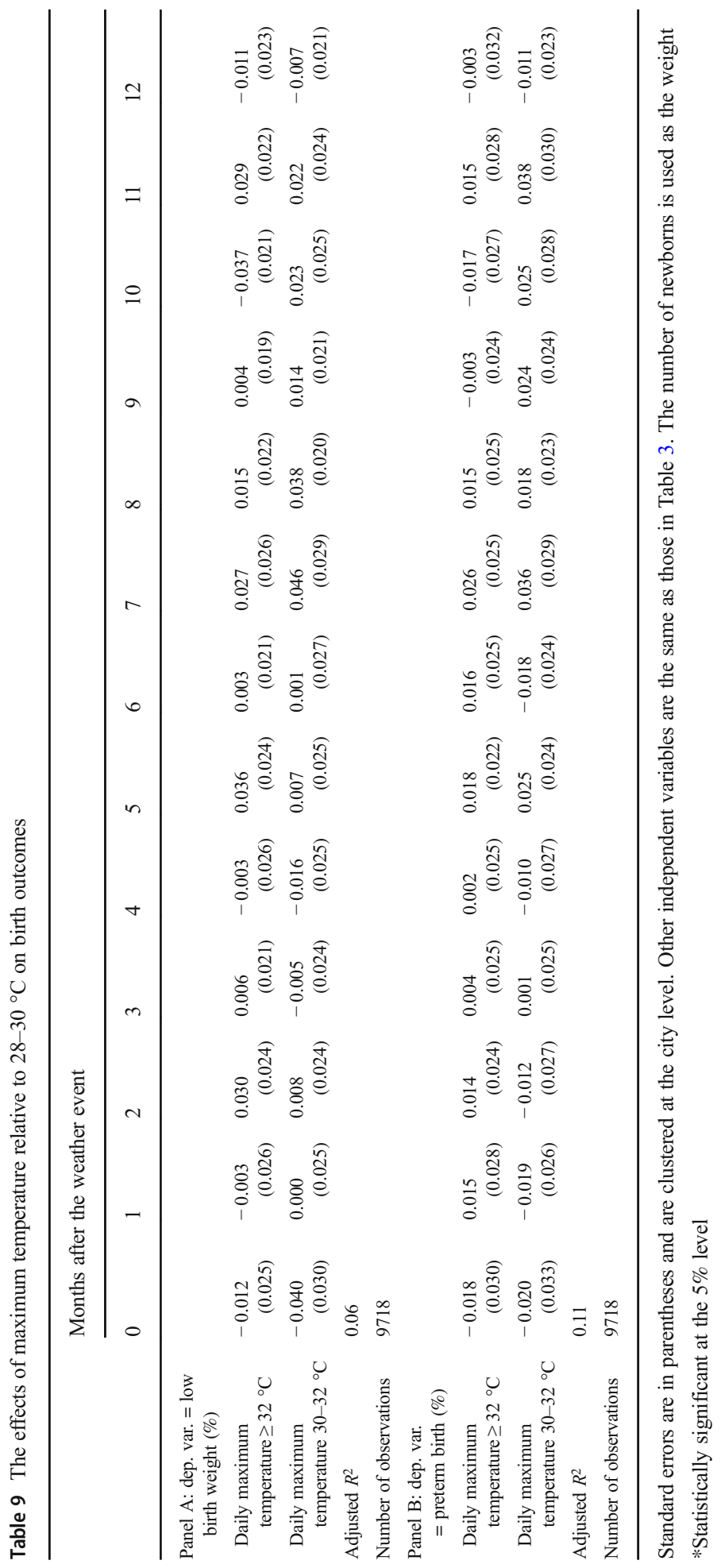


effectively minimize the temperature and economic impact through heat avoidance behavior. Although this study does not examine the temperature-birth rate relationship based on this behavior, future studies should analyze how heat avoidance behavior mitigates the temperature effect.

Acknowledgments The author would like to thank Jaesung Choi, Junseok Hwang, Henny Kim, Jihyeon Kwon, and seminar participants at the Korean Labor Economics Association and Yeungnam University for their valuable comments on this research.

Funding information This research was supported by the Yeungnam University Research Grant (217A580018).

\section{Appendix}

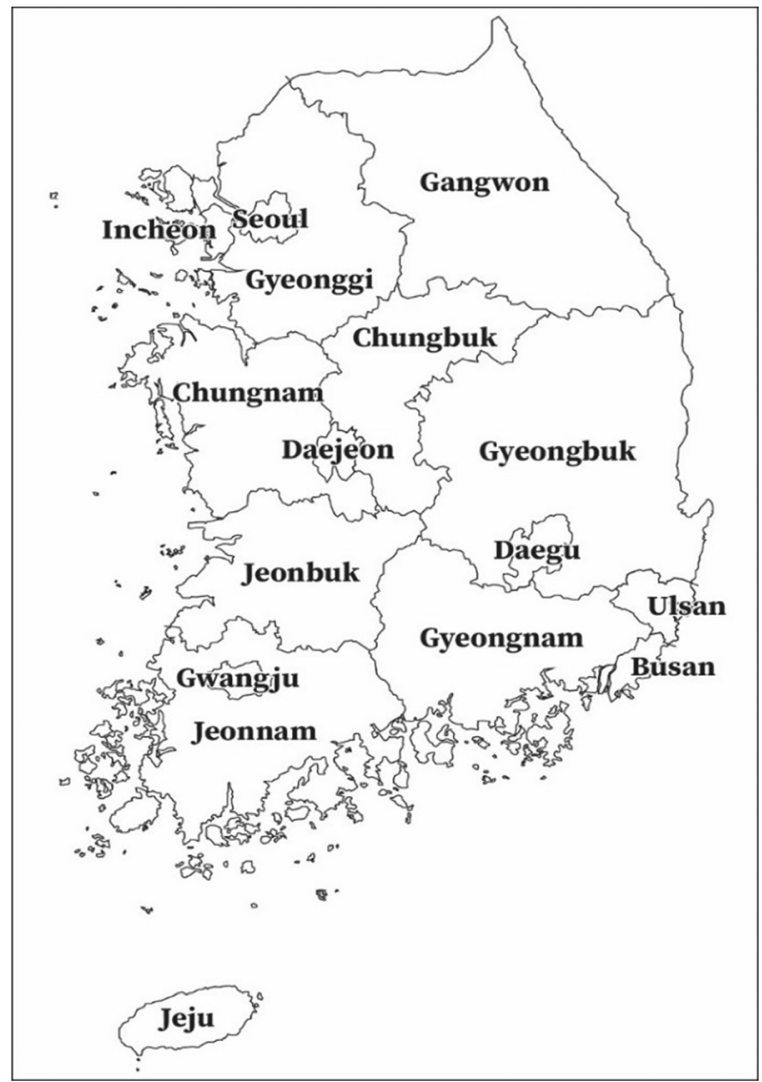

Fig. 1 Map of South Korea 


\section{References}

Almond, D., \& Currie, J. (2011). Killing me softly: the fetal origins hypothesis. The Journal of Economic Perspectives, 25(3), 153-172. https://doi.org/10.1257/jep.25.3.153.

Almond, D., Edlund, L., \& Palme, M. (2009). Chernobyl's subclinical legacy: prenatal exposure to radioactive fallout and school outcomes in Sweden. Quarterly Journal of Economics, 124(4), 1729-1772. https://doi. org/10.1162/qjec.2009.124.4.1729.

Andalón, M., Azevedo, J. P., Rodríguez-Castelán, C., Sanfelice, V., \& Valderrama-González, D. (2016). Weather shocks and health at birth in Colombia. World Development, 82, 69-82. https://doi.org/10.1016/j. worlddev.2016.01.015.

Bai, L., et al. (2014). The effects of summer temperature and heat waves on heat-related illness in a coastal city of China 2011-2013. Environmental Research, 132, 212-219. https://doi.org/10.1016/j. envres.2014.04.002.

Barreca, A. (2012). Climate change, humidity, and mortality in the United States. Journal of Environmental Economics and Management, 63(1), 19-34. https://doi.org/10.1016/j.jeem.2011.07.004.

Barreca, A., Deschenes, O., \& Guldi, M. (2018). Maybe next month? Temperature shocks and dynamic adjustments in birth rates. Demography, 55(4), 1269-1293. https://doi.org/10.1007/s13524-018-0690-7.

Basu, R., Malig, B., \& Ostro, B. (2010). High ambient temperature and the risk of preterm delivery. American Journal of Epidemiology, 172(10), 1108-1117. https://doi.org/10.1093/aje/kwq170.

Black, S. E., A. Bütikofer, P. J. Devereux, and K. G. Salvanes. 2013. "This is only a test? Long-run impacts of prenatal exposure to radioactive fallout." (No. w18987. National Bureau of Economic Research). https://doi.org/10.3386/w18987.

Chen, Z., et al. (2003). Seasonal variation and age-related changes in human semen parameters. Journal of Andrology, 24(2), 226-231. https://doi.org/10.1002/j.1939-4640.2003.tb02666.x.

Cho, H. (2017). The effects of summer heat on academic achievement: a cohort analysis. Journal of Environmental Economics and Management, 83, 185-196. https://doi.org/10.1016/j.jeem.2017.03.005.

Cummings, D. R. (2010). Human birth seasonality and sunshine. American Journal of Human Biology, 22(3), 316-324. https://doi.org/10.1002/ajhb.20987.

Dadvand, P., et al. (2011). Climate extremes and the length of gestation. Environmental Health Perspectives, 119(10), 1449-1453. https://doi.org/10.1289/ehp.1003241.

Dell, M., Jones, B. F., \& Olken, B. A. (2012). Temperature shocks and economic growth: evidence from the last half century. American Economic Journal: Macroeconomics, 4(3), 66-95. https://doi.org/10.1257 /mac.4.3.66.

Dell, M., Jones, B. F., \& Olken, B. A. (2014). What do we learn from the weather? The new climate-economy literature. Journal of Economic Literature, 52(3), 740-798. https://doi.org/10.1257/jel.52.3.740.

Deschênes, O., Greenstone, M., \& Guryan, J. (2009). Climate change and birth weight. The American Economic Review, 99(2), 211-217. https://doi.org/10.1257/aer.99.2.211.

Graff Zivin, J. S., \& Neidell, M. (2014). Temperature and the allocation of time: implications for climate change. Journal of Labor Economics, 32(1), 1-26. https://doi.org/10.1086/671766.

Graff Zivin, J., Hsiang, S. M., \& Neidell, M. (2018). Temperature and human capital in the short- and longrun. Journal of the Association of Environmental and Resource Economists, 5(1), 77-105. https://doi. org/10.1086/694177.

Habeeb, D., Vargo, J., \& Stone, B. (2015). Rising heat wave trends in large US cities. Natural Hazards, 76(3), 1651-1665. https://doi.org/10.1007/s11069-014-1563-z.

Hoynes, H., Schanzenbach, D. W., \& Almond, D. (2016). Long-run impacts of childhood access to the safety net. The American Economic Review, 106(4), 903-934. https://doi.org/10.1257/aer.20130375.

Hsiang, S. M. (2016). Climate econometrics. Annual Review of Resource Economics, 8, 43-75. https://doi. org/10.1146/annurev-resource-100815-095343.

Huber, S., \& Fieder, M. (2009). Strong association between birth month and reproductive performance of Vietnamese women. American Journal of Human Biology, 21(1), 25-35. https://doi.org/10.1002 /ajhb.20799.

Intergovernmental Panel on Climate Change. 2014. "Climate change 2014: mitigation of climate change." Cambridge University Press Cambridge United Kingdom and New York NY USA.

Isen, A., M. Rossin-Slater, and R. Walker. 2015. "Heat and long-run human capital formation." Unpublished manuscript.

Jacob, B., Lefgren, L., \& Moretti, E. (2007). The dynamics of criminal behavior: evidence from weather shocks. The Journal of Human Resources, 42(3), 489-527. https://doi.org/10.3368/jhr.XLII.3.489. 
Lam, D. A. and J. A. Miron. 1991. "Temperature and the seasonality of births. In Temperature and environmental effects on the testis, Adrian Zorgniotti, 73-88. Plenum Press.

Lam, D. A., \& Miron, J. A. (1996). The effects of temperature on human fertility. Demography, 33(3), 291305. https://doi.org/10.2307/2061762.

Lam, D. A., Miron, J. A., \& Riley, A. (1994). Modeling seasonality in fecundability conceptions and births. Demography, 31(2), 321-346. https://doi.org/10.2307/2061888.

Lee, S. J., Hajat, S., Steer, P. J., \& Filippi, V. (2008). A time-series analysis of any short-term effects of meteorological and air pollution factors on preterm births in London, UK. Environmental Research, 106(2), 185-194. https://doi.org/10.1016/j.envres.2007.10.003.

Levine, R. J., et al. (1990). Differences in the quality of semen in outdoor workers during summer and winter. The New England Journal of Medicine, 323(1), 12-16. https://doi.org/10.1056/NEJM199007053230103.

Levitas, E., Lunenfeld, E., Weisz, N., Friger, M., \& Har-Vardi, I. (2013). Seasonal variations of human sperm cells among 6455 semen samples: a plausible explanation of a seasonal birth pattern. American Journal of Obstetrics and Gynecology, 208(5), 406.e1-406.e6. https://doi.org/10.1016/j.ajog.2013.02.010.

Mao, H., Feng, L., \& Yang, W. X. (2017). Environmental factors contributed to circannual rhythm of semen quality. Chronobiology International, 34(3), 411-425. https://doi.org/10.1080/07420528.2017.1280046.

Markey, P. M., \& Markey, C. N. (2013). Seasonal variation in internet keyword searches: a proxy assessment of sex mating behaviors. Archives of Sexual Behavior, 42(4), 515-521. https://doi.org/10.1007/s10508012-9996-5.

McMorris, T., et al. (2006). Heat stress plasma concentrations of adrenaline noradrenaline 5hydroxytryptamine and cortisol mood state and cognitive performance. International Journal of Psychophysiology, 61(2), 204-215. https://doi.org/10.1016/j.ijpsycho.2005.10.002.

Nybo, L., Rasmussen, P., \& Sawka, M. N. (2014). Performance in the heat-physiological factors of importance for hyperthermia-induced fatigue. Comprehensive Physiology, 4, 657-689. https://doi. org/10.1002/cphy.c130012.

Porter, K. R., Thomas, S. D., \& Whitman, S. (1999). The relation of gestation length to short-term heat stress. American Journal of Public Health, 89(7), 1090-1092. https://doi.org/10.2105/ajph.89.7.1090.

Ranson, M. (2014). Crime, weather, and climate change. Journal of Environmental Economics and Management, 67(3), 274-302. https://doi.org/10.1016/j.jeem.2013.11.008.

Robine, J. M., et al. (2008). Death toll exceeded 70000 in Europe during the summer of 2003. Comptes Rendus Biologies, 331(2), 171-178. https://doi.org/10.1016/j.crvi.2007.12.001.

Roenneberg, T., \& Aschoff, J. (1990). Annual rhythm of human reproduction: II. Environmental correlations. Journal of Biological Rhythms, 5(3), 217-239. https://doi.org/10.1177/074873049000500304.

Sanders, N. J. (2012). What doesn't kill you makes you weaker: prenatal pollution exposure and educational outcomes. The Journal of Human Resources, 47(3), 826-850. https://doi.org/10.3368/jhr.47.3.826.

Seiver, D. A. (1985). Trend and variation in the seasonality of U.S. fertility 1947-1976. Demography, 22(1), 89-100. https://doi.org/10.2307/2060988.

Seiver, D. A. (1989). Seasonality of fertility: new evidence. Population and Environment, 10(4), $245-257$. https://doi.org/10.1007/BF01255839.

Sorensen, C., Murray, V., Lemery, J., \& Balbus, J. (2018). Climate change and women's health: impacts and policy directions. PLoS Medicine, 15(7), e1002603. https://doi.org/10.1371/journal.pmed.1002603.

Strand, L. B., Barnett, A. G., \& Tong, S. (2011). The influence of season and ambient temperature on birth outcomes: a review of the epidemiological literature. Environmental Research, 111(3), 451-462. https://doi.org/10.1016/j.envres.2011.01.023.

Tustin, K., Gross, J., \& Hayne, H. (2004). Maternal exposure to first trimester sunshine is associated with increased birth weight in human infants. Developmental Psychobiology: The Journal of the International Society for Developmental Psychobiology, 45(4), 221-230. https://doi.org/10.1002/dev.20030.

Wilde, J., Apouey, B. H., \& Jung, T. (2017). The effect of ambient temperature shocks during conception and early pregnancy on later life outcomes. European Economic Review, 97, 87-107. https://doi.org/10.1016 /j.euroecorev.2017.05.003.

Yackerson, N., Piura, B., \& Sheiner, E. (2008). The influence of meteorological factors on the emergence of preterm delivery and preterm premature rupture of membrane. Journal of Perinatology, 28(10), 707-711. https://doi.org/10.1038/jp.2008.69.

Publisher's note Springer Nature remains neutral with regard to jurisdictional claims in published maps and institutional affiliations. 